\title{
Pengaruh Pemberian Fitobiotik Minyak Buah Merah dengan Teknologi Nanoenkapsulasi terhadap Ukuran Organ Dalam Broiler di KSTM Hidayattullah Kabupaten Manokwari
}

\author{
Al Halimu Maswatu ${ }^{1 *}$, Ni Putu Vidia Tiara Timur ${ }^{2}$, Purwanta $^{3}$ \\ ${ }^{1,2,3}$ Program Studi Penyuluhan Peternakan dan Kesejahteraan Hewan, Politeknik Pembangunan \\ Pertanian Manokwari \\ *Corresponding author: almaswatu621@gmail.com
}

\begin{abstract}
Abstrak
Penelitian ini bertujuan untuk mengetahui pengaruh pemberian fitobiotik dengan teknologi nanoenkapsulasi minyak buah merah pada organ dalam (hati, jantung, gizzard, usus halus, ginjal dan pankreas) ayam broiler. Penelitian ini bertujuan untuk mengetahui dan mengukur tingkat pengetahuan santri di KSTM Hidayatullah tentang penggunaan fitobiotik nanoenkapsulasi minyak buah merah. Metode yang digunakan dalam analisis data pada penelitian ini adalah Microsoft Excel dan DMRT sedangkan, untuk evaluasi penyuluhan menggunakan analisis data SPSS. Hasil penelitian ini menunjukkan bahwa pada organ ginjal terjadi perbedaan yang nyata, dari masingmasing perlakuan yang diberikan, perlakuan terbaik pada penelitian ini, yaitu pemberian pada dosis 5\% atau $25 \mathrm{ml}$ pada air minum. Kegiatan penyuluhan dihadiri oleh para santri Pesantren Hidayatullah Andai yang tergabung di dalam KSTM (Kelompok Santri Tani Milenial). Metode penyuluhan yang digunakan, yaitu metode pendekatan kelompok dan pendekatan individu. Berdasarkan hasil pre-test dan pos-test terdapat perubahan pengetahuan dari nilai rata-rata 33,95 menjadi 36,90 .
\end{abstract}

Kata kunci: Broiler, Fitobiotik, Minyak buah merah, Organ dalam

\begin{abstract}
This study aims to determine the effect of phytobiotic administrationwith nanoencapsulation technology of red fruit oil in the internal organs (liver, heart, gizzard, small intestine, kidney and pancreas) broiler chickens. This study aims to determine and measure the level of knowledge of students in KSTM Hidayatullah about the use of phytobiotic nanoencapsulation of red fruit oil. The method used in data analysis in this study is Microsoft Excel and DMRTwhereas, for the evaluation of counseling using SPSS data analysis. The results of this study indicate that there is a significant difference in the kidney organ, from each treatment given, the best treatment in this study, namely giving at a dose of $5 \%$ or $25 \mathrm{ml}$ in drinking water. The counseling activity was attended by students of the Islamic Boarding School Hidayatullah Andai who were members of the KSTM (Millennial Santri Farmers Group). Counseling methods used, namely the group approach and individual approaches. Based on pre-test and post-test resultsthere is a change of knowledge from an average value of 33.95 to 36.90 .
\end{abstract}

Keywords: Broiler, Phytobiotic, Red fruit oil, Viscera 
Prosiding Seminar Nasional Pembangunan dan Pendidikan Vokasi Pertanian

Politeknik Pembangunan Pertanian Manokwari, 14 November 2020

e ISSN : 2774-1982

\section{PENDAHULUAN}

Ternak ayam pada daerah tropis sering terpapar suhu tinggi sehingga menimbulkan stress pada ternak. Kedaan ini menyebabkan respon pada tubuh untuk beradaptasi pada lingkungan yang abnormal. Proses adaptasi ini menyebabkan pelepasan hormon dan memerlukan pergantian energi serta protein yang tinggi sehingga mengakibatkan penurunan pertumbuhan, reproduksi dan kesehatan (Utami dan Didik, 2016).

Para peternak intensif seperti peternak ayam dan sapi secara rutin memberikan growth promotor dalam bentuk antibotik dengan bertujuan untuk merangsang pertumbuhan dan menekan angka kematian (Daud, 2005). Antibiotik merupakan salah satu jenis feed additive yang digunakan pada campuran pakan dan air minum. Tujuan dari pengguna anantibiotik, yaitu untuk meningkatkan produktivitas, kesehatan, dan keadaan gizi ternak (Hasrullah, 2017). Semenjak diberlakukannya Peraturan Menteri Pertanian RI Nomor 14 Tahun 2017 tentang pelarangan penggunaan antibiotik dalam budidaya ternak, banyak upaya yang dilakukan untuk menggantikan penggunaan antibiotik. Penggunaan antibiotik sebagai growth promotor dapat menyebabkan menurunnya tingkat kesehatan dan meningkatnya mortalitas pada hewan ternak (Sugiharto, 2016). Buah merah merupakan salah satu tanaman yang mengandung senyawa bioaktif seperti karotenoid dan tokoferol (vitamin E) yang berfungsi sebagai antioksidan yang dapat menangkal radikal bebas (Roreng et al., 2014)

Fitobiotik adalah aditif ransum yang berasal dari bahan-bahan herbal (Zuprizal dalam Kusumasari, 2012). Fitobiotik mengandung zat bioaktif sehingga dimanfaatkan sebagai natural growth promotor sebagai pengganti antibiotik dan berfungsi juga sebagai anti bakteria (Putra, 2018). Papua sangat terkenal dengan buah merah (Pandanus conoideus) yang digunakan sebagai obat herbal dan dipercaya untuk menyembuhkan berbagai penyakit pada manusia. Minyak buah merah juga bisa dimanfaatkan untuk menjaga kesehatan ternak sebagai obat herbal. Oleh karena itu, memberikan minyak buah merah dengan teknologi yang sudah ada, yaitu fitobiotik nanoenkapsulasi yang diberikan pada air minum ayam broiler. Sehingga kinerja organ dalam ayam broiler akan baik dapat terhindar dari penyakit serta mampu meningkatkan berat badan.

Kelompok Santri Tani Milenial (KSTM) merupakan salah satu program Kementerian Pertanian tahun 2019 berdasarkan Peraturan Menteri Pertanian Nomor 09 tahun 2019 tentang Pedoman Gerakan Pembangunan SDM Pertanian Menuju Lumbung Pangan Dunia 2045. Dalam program Kementerian Pertanian tersebut, salah satu provinsi yang mendapat bantuan adalah Provinsi Papua Barat tepatnya di Kabupaten Manokwari, 
Prosiding Seminar Nasional Pembangunan dan Pendidikan Vokasi Pertanian Politeknik Pembangunan Pertanian Manokwari, 14 November 2020

e ISSN : 2774-1982

Kota Sorong dan Kabupaten Sorong. Kabupaten Manokwari memiliki 3 (tiga) KSTM salah satunya adalah KSTM yang berlokasi di Pondok Pesantren Hidayatullah, Kelurahan Andai, Distrik Manokwari Selatan, Kabupaten Manokwari, Provinsi Papua Barat. Anggota KSTM Hidayatullah terdiri dari 2 (dua) kelompok di dalamnya, setiap kelompok terdiri dari 20 orang sehingga total keseluruhan anggota adalah 40 orang. Setiap KSTM mendapat bantuan paket budidaya ayam kampung super 1000 ekor, pakan $1000 \mathrm{~kg}$, paket obat-obatan hewan dan paket bantuan kandang.

Berdasarkan uraian tersebut, penulis membuat kajian dan melaksanakan penyuluhan dengan materi pembuatan fitobiotik nanoenkapsulasi minyak buah merah terhadap performa ayam broiler umur 1 sampai 4 minggu di KSTM Hidayatullah. Kajian dan penyuluhan bertujuan agar pengetahuan santri tani milenial meningkat, dapat membuka wawasan tentang perunggasan khususnya ayam broiler, dapat menjadi pembelajaran berwirausaha ayam broiler serta dapat memanfaatkan potensi buah merah yang terdapat di Provinsi Papua Barat khususnya Kabupaten Manokwari.

\section{METODE}

\section{Lokasi dan Waktu}

Kegiatan penelitian ini telah dilaksanakan pada bulan Maret sampai dengan April 2020 yang berlokasi di Kampus Politeknik Pembangunan Pertanian (POLBANGTAN) Manokwari. Penyuluhan dilaksanakan pada bulan Mei 2020 KSTM Hidayatullah Kelurahan Andai, Distrik Manokwari Selatan, Kabupaten Manokwari, Provinsi Papua Barat.

\section{Alat dan Bahan}

Alat yang digunakan dalam penelitian meliputi kandang, timbangan digital, gelas ukur (beaker glass), label, blender, termohigrometer, lampu, tirai plastik, ember, tempat pakan, tempat minum dan alat tulis. Dalam kegiatan penyuluhan alat yang digunakan antara lain kuisioner tes awal dan tes akhir, folder, kamera, alat tulis dan bahan-bahan pembuatan fitobiotik nanoenkapsulasi minyak buah merah.

Bahan yang digunakan dalam penelitian ini meliputi minyak buah merah, kitosan, Sodium Tripolyphosphate (STPP), asam asetat, 36 ekor DOC (Day Old Chick) ayam broiler jantan strain CP 707, pakan CP521 dan air minum.

\section{Pembuatan Nanoenkapsulasi}

Proses nanoenkapsulasi menggunakan metode gelasi ionik dengan mencampurkan $0,625 \%$ kitosan (kitosan yang telah dilarutkan dalam 2,50\% asam asetat, diaduk dengan 
Prosiding Seminar Nasional Pembangunan dan Pendidikan Vokasi Pertanian

Politeknik Pembangunan Pertanian Manokwari, 14 November 2020

e ISSN : 2774-1982

menggunakan blender selama 2 menit) dan 0,75\% STPP (yaitu 0,75\% STPP yang telah dilarutkan dengan aquades dan diaduk menggunakan blender selama 2 menit). Perbandingan larutan nanoenkapsulasi sebagai fitobiotik yaitu minyak buah merah : kitosan dan STPP (0,81:0,16:0,03) (Sundari, 2014; Syaefullah et al., 2019; Timur et al., 2020).

\section{Proedur kerja}

Fitobiotik nanoenkapsulasi minyak buah merah diaplikasikan pada saat pagi hari, kemudian pada sore hari ayam hanya diberikan air minum tanpa fitobiotik nanoenkapsulasi minyak buah merah. Pemberian pakan dilakukan 1 (satu) kali dalam sehari yaitu pada sore hari. Suhu dan kelembaban kandang dicatat 3 (tiga) kali sehari yaitu pagi, siang dan sore. Sedangkan penimbangan bobot badan dilakukan setiap 7 (tujuh) hari sekali.

\section{Rancangan Penelitian}

Metode yang digunakan dalam penelitian ini adalah Rancangan Acak Lengkap (RAL) yang terdiri dari 3 perlakuan dan 4 ulangan, masing-masing ulangan terdiri dari 3 ekor ayam. Perlakuan yang diberikan adalah:

$\mathrm{P} 0=$ air minum tanpa aditif (kontrol).

$\mathrm{P} 1=$ air minum $+2,5 \%$ nanoenkapsulasi bioaktif minyak buah merah.

$\mathrm{P} 2=$ air minum $+5 \%$ nanoenkapsulasi bioaktif minyak buah merah.

\section{Variabel dan Pengukuran}

Persentase bobot organ dalam (hati, jantung, gizzard, usus halus, ginjal dan pankreas) diperoleh dari penimbangan antara bobot organ dengan bobot hidup ayam dikalikan dengan 100\% (setelah dipisahkan lemak yang melekat) (Auaza, 2010).

\section{Analisis Data}

Analisis data menggunakan Rancangan Acak Lengkap (RAL) Pola Searah dengan 3 perlakuan dan 4 ulangan menggunakan program analisis data Microsoft Excel dan DMRT.

\section{Rancangan Penyuluhan}

Tujuan penyuluhan ini adalah untuk mengetahui peningkatkan pengetahuan kelompok KSTM dalam menggunakan fitobiotik nanoenkapsulasi minyak buah merah terhadap kinerja organ dalam ayam broiler. Kegiatan penyuluhan diikuti oleh 20 orang responden dengan metode pendekatan kelompok dan idividu melalui ceramah, diskusi dan demonstrasi cara. Sebelum dilakukan penyuluhan, responden diberikan tes awal (pre test) untuk mengetahui tingkat pengetahuan peternak sebelum diberi materi penyuluhan. Setelah 
Prosiding Seminar Nasional Pembangunan dan Pendidikan Vokasi Pertanian

Politeknik Pembangunan Pertanian Manokwari, 14 November 2020

e ISSN : 2774-1982

kegiatan penyuluhan responden diberi tes akhir (post test). Hasil nilai pre test dan post test dianalisis menggunakan Independent Sample T Test, yaitu untuk membandingkan nilai rata-rata nilai pre test dan post test.

\section{HASIL DAN PEMBAHASAN}

\section{Persentase Organ Dalam Ayam Broiler}

Hasil penelitian selama 4 minggu (28 hari) pada ayam broiler yang diberikan fitobiotik nanoenkapsulasi minyak buah merah terhadap persentase berat hati, jantung, gizzard, usus halus, ginjal dan pankreas dapat dilihat pada Tabel 1 dan 2.

Tabel 1. Persentase Berat Hati, Jantung, Gizzard

\begin{tabular}{cccc}
\hline Perlakuan & $\begin{array}{c}\text { Hati } \\
(\%)\end{array}$ & $\begin{array}{c}\text { Jantung } \\
(\%)\end{array}$ & $\begin{array}{c}\text { Gizzard } \\
(\%)\end{array}$ \\
\hline P0 & 2,65 & 0,68 & 2,37 \\
P1 & 2,70 & 0,64 & 2,43 \\
P2 & 2,38 & 0,73 & 2,42 \\
\hline
\end{tabular}

Tabel 2. Persentase Berat, Usus Halus, Ginjal, Pankreas

\begin{tabular}{cccc}
\hline Perlakuan & $\begin{array}{c}\text { Usus Halus } \\
(\%)\end{array}$ & $\begin{array}{c}\text { Ginjal } \\
(\%)\end{array}$ & $\begin{array}{c}\text { Pankreas } \\
(\%)\end{array}$ \\
\hline P0 & 3,46 & 0,53 & 0,40 \\
P1 & 3,51 & 0,64 & 0,46 \\
P2 & 3,75 & $0,78^{\mathrm{b}}$ & 0,46 \\
\hline
\end{tabular}

\section{Hati}

Rataan persentase pada Tabel 1 tidak menunjukkan perbedaan yang nyata pada persentase bobot hati ayam broiler $(\mathrm{P}>0,05)$ terhadap setiap perlakuan. Rataan persentase terhadap bobot hati di setiap perlakuan yaitu 2,65\%, 2,70\% dan 2,38\%. Menurut Siregar (2011) bobot normal hati berkisar 1,70\%-2,80\% dari bobot potong. Berdasarkan hasil penelitian di atas, pemberian fitobiotik nanoenkapsulasi minyak buah merah tidak mempengaruhi berat normal dari hati karena tidak menunjukkan perbedaan yang nyata pada masing-masing perlakuan yang dilakukan dan tidak mempengaruhi berat normal hati. Hal ini dapat disebabkan karena adanya kandungan tokoferol dan juga betakaroten yang terkandung pada buah merah yang diberikan sebagai fitobiotik nanoenkapsulasi pada air minum dan berguna untuk meningkatkan kekebalan tubuh dan antioksidan (Budi dan Paimin, 2005). Berat hati masih dalam kisaran normal dikarenakan pemberian fitobiotik ini dapat membantu kerja hati sehingga tidak menambah kerja hati lebih berat sehingga 
Prosiding Seminar Nasional Pembangunan dan Pendidikan Vokasi Pertanian

Politeknik Pembangunan Pertanian Manokwari, 14 November 2020

e ISSN : 2774-1982

beratnya masih dalam kisaran normal. Pada penelitian ini tidak terlihat adanya kelainan pada hati. Kelainan pada hati biasanya dapat dilihat dari perubahan fisiologi pada hati dengan ciri-cirinya yaitu adanya pembengkakan dan penebalan suatu lobi pada hati. Hal tersebut yang dapat membuat penambahan bobot pada hati (Spector dalam Yasir Gunawan, 2011).

\section{Jantung}

Rataan persentase jantung pada Tabel 1 menunjukkan bahwa pemberian fitobiotik nanoenkapsulasi minyak buah merah tidak memberikan perbedaan yang nyata terhadap persentase jantung ayam broiler $(\mathrm{P}>0,05)$. Rataan persentase bobot jantung di setiap perlakuan, yaitu $0,68 \%, 0,64 \%$ dan $0,73 \%$. Berat jantung berdasarkan pada data di atas masih dalam kisaran berat normal. Menurut (Aqsah et al., 2016) berat normal jantung berkisar 0,5\%-1,42\% dari bobot potong. Resang dalam Yasir Gunawan (2011) mengatakan bahwa jika dalam darah ada mengandung racun dan antinutrisi maka akan mengakibatkan kontraksi pada jantung yang berlebihan, sehingga mengakibatkan pembengkakkan pada jantung. Dari data penelitian di atas menunjukkan bahwa jantung tidak melebihi berat normalnya, hal ini disebabkan karena minyak buah merah merupakan bahan non toksik dan aman digunakan sebagai fitobiotik nanoenkapsulasi yang diberikan pada air minum ayam broiler, tidak menambah kinerja jantung dan menghambat sirkulasi darah.

\section{Gizzard}

Rataan persentase gizzard pada Tabel 1 menunjukkan bahwa pemberian fitobiotik nanoenkapsulasi minyak buah merah tidak menunjukkan perbedaan yang nyata pada persentase berat gizzard $(\mathrm{P}>0,05)$. Rataan persentase gizzard di setiap perlakuan, yaitu $2,37 \%, 2,43 \%$ dan 2,42\%. Bobot normal persentase gizzard berkisar 1,6\%-2,3\% dari bobot potong (Simora, 2011). Data penelitian di atas berbeda dengan bobot normal dari gizzard. Weiss dan Scott dalam Rosyani (2013) menyatakan bahwa pakan yang mengandung serat tinggi dapat memperbesar ukuran dari gizzard. Kandungan serat yang tinggi pada pakan akan memacu gizzard untuk lebih banyak bekerja secara fisiologi dalam proses mencerna serat baik secara mekanik atau enzimatis. Pada penelitian ini Serat yang terkandung di dalam buah merah juga dapat menambah kinerja gizzard untuk lebih berat sehingga bisa membuat bobot gizzard dapat bertambah besar. Rosyani (2013) juga mengatakan bahwa ukuran gizzard dapat dipengaruhi oleh tingkat konsumsi ransum dan jenis makanannya sehingga membuat penebalan pada urat gizzard sehingga ukuran gizzard menjadi lebih besar dan lebih berat. 
Prosiding Seminar Nasional Pembangunan dan Pendidikan Vokasi Pertanian Politeknik Pembangunan Pertanian Manokwari, 14 November 2020

e ISSN : 2774-1982

\section{Usus Halus}

Rataan persentase usus halus pada Tabel 2 memperlihatkan bahwa pemberian fitobiotik nanoenkapsulasi minyak buah merah tidak menunjukkan perbedaan yang nyata ( $P>0,05)$. Rataan persentase usus halus ayam broiler yaitu 3,46\%, 3,51\% dan 3,75\%. Bobot normal dari usus halus, yaitu 2,34\%-3,05\% dari bobot potong ayam broiler (Tambunan, 2007). Hasil penelitian di atas menunjukkan bahwa usus halus mempunyai bobot yang lebih berat dari bobot normalnya. Menurut yang et al. (2013) peningkatan bobot dari usus halus sejalan dengan penyerapan nutrisi yang di serap oleh usus halus. Penambahan fitobiotik nanoenkapsulasi pada setiap perlakuan (P1 dan P2) dapat meningkatkan panjang vili dibandingkan dengan yang tidak diberi perlakuan. Peningkatan panjang vili pada usus halus menyebabkan permukaan pada bidang absorbsi menjadi lebih luas sehingga penyerapan nutrisi dapat diserap lebih optimal (Hartono et al., 2016).

\section{Ginjal}

Rataan persentase ginjal pada Tabel 2 menunjukkan bahwa pemberian fitobiotik nanoenkapsulasi minyak buah merah pada ayam broiler menununjukan perbedaan yang nyata $(\mathrm{P}<0.05)$ pada ginjal. Rataan ginjal ayam broiler dari hasil penelitian yaitu $0,53 \%$, 0,64\% dan 0,78 walaupun pada perlakuan P2 ginjal terlihat lebih besar, tetapi ginjal pada penelitian di atas masih berada pada bobot normal. Berdasarkan penelitian dari Hermana et al., (2008) yang menyatakan bahwa bobot normal ginjal berkisar dari 0,43\%-0,84\% dari bobot potong. Kandungan betakaroten yang terdapat pada buah merah berfungsi dalam pemeliharaan sel-sel epitel dan dan menjaga proses metabolisme (Budi, 2005). Selain betakaroten yang terkandung pada buah merah, kandungan tokoferolnya juga berfungsi menjaga integritas membran (Combos, 1992). Ginjal merupakan organ yang mempunyai daya saring dan daya serap kembali, jika terdapat penyerapan racun atau toksik yang banyak masuk ke dalam tubuh maka kinerja dari ginjal akan semakin berat sehingga akan menambah bobot dari ginjal (Ressang dalam Yasir Gunawan 2011). Berdasarkan hasil penelitian yang telah dilakukan, pemberian fitobiotik nanoenkapsulasi buah merah pada ayam broiler tidak mempengaruhi atau menambah kinerja dari ginjal. Berdasarkan hasil analisis data di atas terdapat perubahan yang nyata sehingga dilakukan lagi uji lanjutan dengan metode DMRT. Hasil uji lanjutan memperlihatkan bahwa perlakuan yang terbaik berada pada P2 yang diberikan 5\% fitobiotik nanoenkapsulasi minyak buah merah.

\section{Pankreas}


Prosiding Seminar Nasional Pembangunan dan Pendidikan Vokasi Pertanian Politeknik Pembangunan Pertanian Manokwari, 14 November 2020

e ISSN : 2774-1982

Rataa persentase pankreas pada Tabel 2 di atas menunjukkan bahwa tidak ada perbedaan yang nyata $(\mathrm{P}>0,05)$ dari setiap perlakuan yang diberikan. Rataan bobot pankreas dari hasil penelitian di atas yaitu $0,40 \%, 0,46 \%$ dan $0,46 \%$ dari bobot potong. Berat normal pankreas yaitu 0,25\%-0,40\% dari berat potong (Simamora, 2011). Hal ini menunjukkan bahwa pemberian fitobiotik nanoenkapsulasi minyak buah merah pada ayam broiler tidak membuat kinerja dari pankreas semakin berat sehingga bobot pankreas masih dalam kisaran bobot normal. Tokoferol juga bisa membantu kinerja dari pankreas dalam menggunakan dan mengatur penyerapan nutrisi berupa energi yang akan diserap oleh tubuh di dalam sistem pencernaan. Faktor-faktor yang dapat mempengaruhi penambahan bobot dari pankreas, yaitu genetic, tingkah laku dan lingkungan (Aqsah et al., 2016).

\section{Evaluasi Penyuluhan}

Tingkat perubahan pengetahuan diukur dengan membandingkan nilai rata-rata pretest dan post-test dengan menggunakan uji T test. Pertanyaan untuk mengukur nilai tingkat pengetahuan berbentuk kuisioner sebanyak 10 soal yang dibagikan kepada 20 orang responden mengetahui adakah perbedaan mean atau rata-rata dari nilai pre-test dan posttest Hasil analisis uji $\mathrm{T}$ test menggunakan SPSS menunjukkan bahwa tidak terdapat perbedaan rata-rata (signifikan) antara tes awal (pre test) dan tes akhir (post test) karena nilai Sig.(2-tailed) $>0,05$. Untuk nilai rata-rata tes awal yaitu berjumlah 33,95 dan untuk nilai rata-rata tes akhir yaitu 36,90 .

\section{KESIMPULAN DAN SARAN}

Pemberian fitobiotik minyak buah merah dengan teknologi nanoenkapsulasi tidak mempengaruhi atau memperberat kinerja organ dalam seperti hati, ginjal, jantung dan pankreas. Tetapi pada gizzard dan usus halus terjadi perubahan ukuran dari berat normal. Sedangkan dari penelitan ini, yang terdapat perbedaan yang nyata pada ginjal dari perbedaan pada ginjal ini terdapat pada $\mathrm{P} 2$, oleh karena dari perlakuan pemberian fitobiotik minyak buah merah dengan teknologi nanoenkapsulasi yang paling terbaik adalah perlakian dari P2 yaitu pemberian dengan dosis sebanyak 5\% atau $25 \mathrm{ml}$.

Responden yang mengikuti kegiatan penyuluhan di KSTM Pesantren Hidayatullah dapat memahami bahaya penggunaan antibiotik dan keuntungan menggunakan fitobiotik pada ternaknya. Setelah melakukan penyuluhan terdapat peningkatan pengetahuan tentang fitobiotik nanoenkapsulasi minyak buah merah. 


\section{DAFTAR PUSTAKA}

Aqsa, A.D., Kiramang, K. and Hidayat, M.N. 2016. Profil Organ Dalam Ayam Pedaging (broiler) Yang Diberi Tepung Daun Sirih (piper battle linn) Sebagai Imbuan Pakan. JurnalIlmu Dan Industri Perternakan. 3(1) : 148-159.

Azura, Astuti F. 2010. Efektifitas Pemberian Serbuk Kunyit, Bawang Putih Dan Mineral Zink Terhadap Kadar Kolestrol Darah Dan Bobot Organ Dalam Pada Broiler. Tesis. Program Studi Sistem-sistem Pertanian Konsentrasi Peternakan Program Pascasarjana Unifersitas Hasanudin. Makasar

Budi, I.M, and Paimin, F.R. 2005. Buah Merah. Jakarta: Penebar Swadaya

Combs, Gerald F. 1992. The Vitamin Fundemental Aspects in Nutrition and Health. New York: Academic Press. Inc.

Daud, M. 2005. Performa Ayam Pedaging Yang Diberikan Probiotik Dan Prebiotik Dalam Ransum (Performaces of Broilers That Given Probiotics and Prebiotics In The Ration). Jurnal Ilmu Ternak. Vol 5 No 2, (75-79).

Hasrullah, 2017 Status Hematologis Broiler Dengan Penambahan Fitobiotik Ekstrak Kunyit dan Bawang Putih Dengan Infeksi Bakteri Salmonella Sp.Skripsi. Universitas Hasanuddin Makassar

Hartonon, E. F. N. Iriyanti dan S. Suhermiyati 2016. Efek Penggunaan Simbiotik Terhadap Kondisi Mikroflora dan Histologi Usus Ayam Sentul Jantan, J. Agripet, 16 (2): $97-$ 195.

Kusumasari. Y.F.Y., Yunianto V.D Dan Suprijatna E. 2012. Pemberian Fitobiotik Yang Berasal Dari Mahkota Dewa (Phaieriamacrocarpa) Terhadap Kadar Hemoglobin dan Hematokrit Pada Ayam Broiler. Jurnal. Universitas Diponegoro. Vol. 1, No. 4, Hal. 129-132.

Putra. D.R. 2018. Pemberian Fitobiotik Ekstrak Kunyit Dan Bawang PutihTerhadap Tingkat Kerusakan Organ Hati dan UsusHalus Broiler Yang Diinfeksi. Skripsi. Universitas Hasanuddin Makassar.

Roreng, M.K., N.S. Palupi, and E. Prangdimurti. 2014. Carotenoids from Red Fruit (Pandanus ConoideusLam) Extract are Bioavailable: A Study in Rats. International Organization of Scientific Research Journal of Pharmacy. 4(2): 11-16.

Rosyani, S. 2013. Pemberian Pakan Konsentrat Mengandung Tepung Inti Sawit Yang Ditambahkan Pollard atau Dedak dan Pengaruhnya Terhadap Persentase Organ Dalam Organ Dalam Ayam Broiler. Skripsi Institut Pertanian Bogor. Bogor.

Simora. N. 2011. Performa Produksi Dan Karakteristik Organ DalamAyam Kampung Umur 12-16 Minggu Yang Diinfeksi Cacing Ascaridiagalli Dan Disuplementasi Ekstrak DaunJarak Pagar (Jatropha curcas Linn). Skripsi. FskultasPeternakan. InstitutPertanian Bogor. Bogor.

Siregar, D.Z. 2011. Persentase Karkas dan Pertumbuhan Organ Dalam Ayam Broiler Pada Frekuensi dan Waktu Pemberian Pakan Yang Berbeda. Skripsi. Fakultas Peternakan. Institut Pertanian Bogor.

Sundari, Zuprizal and Martien R. 2014. The Effect Nanocapsule of Turmeric Extracts in Rations on Nutrient Digestibility of Broiler Cikens. Animal Production. 16:107113. 
Syaefullah, B. L., Herawati, M., Timur, N. P. V. T., Bachtiar, E. E., \& Maulana, F. (2019). INCOME OVER FEED COST PADA AYAM KAMPUNG YANG DIBERI NANOENKAPSULASI MINYAK BUAH MERAH (Pandanus conoideus) VIA WATER INTAKE. Jurnal Triton, 10(2), 54-61.

Timur, V., Herawati, M., Syaefullah, B. L., \& Bachtiar, E. (2020). Mortalitas dan Profil Organ Dalam Ayam Kampung yang diberi Fitobiotik Nanoenkapsulasi Minyak Buah Merah (Pandanus conoideus). Jurnal Triton, 11(1), 16-23.

Utami .D .M. R and Didik Pantaya. 2016. Penggunaan Ekstrak Bawang Putih Dalam PakaTerhadap Performa Ayam Broiler Tropis Fase Starter. Jurnal Seminar Nasional Hasil Penelitian dan Pengabdian Masyarakat. ISBN 978-602-14917-2-0.

Yang HM, Wang W, Wang ZY, Wang J, Cao YJ, Chen YH. 2013. Comparative study intestine leght, wighet and digwstibility on different body weight . African Journal of Biotechnology. 12(23): 5097-5100.

Yasir Gunawan. 2011. Organ Dalam Ayam Kampung Unur 10 Minggu Yang Diberi Ransum Mengandung Bungkil Biji Jarak Pagar (Jatropha Curcas L) Terfermentasi Rhizopus Oligosporus. Skripsi. Departemen Ilmu Nutrisi Dan Teknologi Pakan, Fakultas Peternakan, Institute Pertanian Bogor. 